\title{
Soil phenanthrene phytoremediation capacity in bacteria-assisted Spartina densiflora
}

\author{
Jennifer Mesa-Marín a, *, José M. Barcia-Piedras ${ }^{\text {b }}$, Enrique Mateos-Naranjo a , Lucía Cox ${ }^{\text {d, }}$ Miguel Real ${ }^{\text {, }}$,

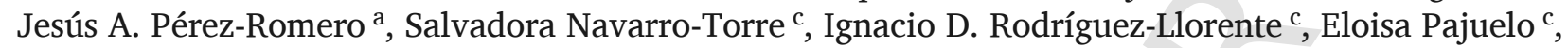 \\ Raquel Parra ${ }^{a}$, Susana Redondo-Gómez ${ }^{\text {a }}$ \\ a Departamento de Biología Vegetal y Ecología, Facultad de Biología, Universidad de Sevilla, Apartado 1095, 41080, Sevilla, Spain \\ b Centro IFAPA Las Torres-Tomejil, Ctra. Sevilla, Cazalla Km. 12,2, 41200, Alcalá Del Río, Sevilla, Spain \\ ${ }^{c}$ Departamento de Microbiologia, Facultad de Farmacia, Universidad de Sevilla, C/ Profesor García González 2, 41012, Sevilla, Spain \\ d Instituto de Recursos Naturales y Agrobiología (CSIC), Reina Mercedes 10, 41012, Sevilla, Spain
}

\section{ARTICLE INFO}

\section{Keywords:}

Phenanthrene

Spartina densiflora

Endophytic bacteria

Phytoremediation

Photosynthesis

\begin{abstract}
A B S T R A C T
Polycyclic aromatic hydrocarbons (PAH) have become a threat for the conservation of wetlands worldwide. The halophyte Spartina densiflora has shown to be potentially useful for soil phenanthrene phytoremediation, but no studies on bacteria-assisted hydrocarbon phytoremediation have been carried out with this halophyte. In this work, three phenanthrene-degrading endophytic bacteria were isolated from $S$. densiflora tissues and used for plant inoculation. Bacterial bioaugmentation treatments slightly improved $S$. densiflora growth, photosynthetic and fluorescence parameters. But endophyte-inoculated $S$. densiflora showed lower soil phenanthrene dissipation rates than non-inoculated $S$. densiflora ( $30 \%$ below) or even bulk soil ( $23 \%$ less). Our work demonstrates that endophytic inoculation on $S$. densiflora under greenhouse conditions with the selected PAH-degrading strains did not significantly increase inherent phenanthrene soil dissipation capacity of the halophyte. It would therefore be advisable to provide effective follow-up of bacterial colonization, survival and metabolic activity during phenanthrene soil phytoremediation.
\end{abstract}

\section{Introduction}

Polycyclic aromatic hydrocarbons (PAH) are organic pollutants widely distributed. Their toxic, mutagenic and carcinogenic effect on living beings is of great environmental concern, so PAH remediation efforts constitute a high priority (Mumtaz and George, 1995). For environmental cleanup, these organic compounds are generally removed through in situ and ex situ remediation methods based on physical and chemical processes (Arthur et al., 2005). These methods are usually characterized by a high operating cost, difficulty in operation and production of secondary pollutants (Pilon-Smits, 2005). Phytoremediation, namely using plants and their microbiome for environmental cleanup, represents a cost effective, non-invasive and eco-friendly remediation method, which in addition enjoys of wide public acceptance (Pandey et al., 2009).

The cordgrass Spartina densiflora Brongn. (Poaceae) is a $\mathrm{C}_{4}$ halophyte, especially present in estuaries around North America, North Africa and southern Europe. Its great photosynthetic and growth rates, together to its capacity to withstand pollutants through phytostabilization and tissue accumulation, make it useful for bioremediation purposes (Cambrollé et al., 2008; Mackova et al., 2006; Redondo-Gómez, 2013). This is especially important in estuarine sediments, highly exposed to PAH pollutants, like oil spills, because of their geomorphological characteristics (Day et al., 2013). In previous greenhouse studies, $S$. densiflora demonstrated natural high Phe tolerance and the capacity for Phe soil removal (Redondo-Gómez et al., 2011). Phenanthrene (Phe) represents a model PAH, commonly present in industrial wastes. Phe poor solubility in water and low molecular weight favor its accumulation in organisms, so they respond rapidly to its presence, thus making them very sensitive and more vulnerable to this PAH (Baker, 1970). Phe impact on other halophytes has been studied by several authors (Cavé-Radet et al., 2019; Hong et al., 2015; Shiri et al., 2016; Van Oosten and Maggio, 2015; Watts et al., 2006; Zhang et al., 2010), and in line with $S$. densiflora, halophytes like Cakile maritima, have demonstrated to decrease Phe phytotoxicity in the substrate (Shiri et al., 2015), through poorly understood mechanisms (Dumas et al., 2016; El Amrani et al., 2015). Moreover, although very scarcely, halophytes mi-

\footnotetext{
* Corresponding author. Dpto. Biología Vegetal y Ecología, Facultad de Biología, Universidad de Sevilla, Avda. Reina Mercedes s/n, 41012, Sevilla, Spain.

Email address: jmesam@us.es (J. Mesa-Marín)
} 
crobiome has been characterized in search of PAH-degrading bacteria (Hong et al., 2015; Launen et al., 2008; Smith et al., 2008; Watts et al., 2006). Focusing on endophytic bacteria, many of them are able to degrade organic contaminants or may introduce pollutant degrading genes in local bacterial population (Phillips et al., 2008; Yousaf et al., 2010). Moreover, endophytes enjoy less nutrient and space competition and more protection from environmental adversities than rhizobacteria (Schulz and Boyle, 2006). What is more, Siciliano et al. (2001) reported that genes encoding for contaminant degradation were much more prevalent in endophytic strains than within microbial communities from rhizosphere and bulk soil. However, no endophyte bacteria-assisted phytoremediation studies have been developed in halophytes.

Considering that plant bacteria interactions have been studied as a promising biotool for the remediation of hydrocarbon-polluted soil and water in other plant species (Khan et al., 2013), our initial hypothesis is that $S$. densiflora Phe phytoremediation capacity may be improved by bacterial inoculation. Therefore, in this work we studied the effect of bacterial inoculation on $S$. densiflora growing in presence of Phe by (1) analysing and comparing the growth and ecophysiological response of bacterial inoculated and non-inoculated $S$. densiflora in Phe-polluted soil and (2) determining differences in their soil Phe-dissipation capacity.

\section{Materials and methods}

\subsection{Isolation and characterization of bacteria from plant tissues}

Spartina densiflora plants were collected from Odiel marshes (Huelva, Spain) $\left(37^{\circ} 13^{\prime} \mathrm{N}-6^{\circ} 57^{\prime} \mathrm{O}\right)$ in October 2013 , they were transported to the laboratory into plastic bags and stored at $4{ }^{\circ} \mathrm{C}$ until the endophytes isolation $(24 \mathrm{~h})$. Cultivable bacteria were isolated from leaves and roots as described in Mesa et al. (2015). Briefly, leaves and roots were surface disinfected separately by immersion and gentle shaking in $70 \%$ (v/ v) ethanol, followed by $5 \%(\mathrm{v} / \mathrm{v})$ sodium hypochlorite and five rinses in sterile distilled water. Next, samples were aseptically macerated with physiological saline solution $(\mathrm{NaCl} 0.9 \% \mathrm{w} / \mathrm{v})$ into a sterile mortar. Then, $100 \mu \mathrm{l}$ of each sample extract were plated in triplicate into TSA $0.3 \mathrm{M} \mathrm{NaCl}$ plates. This medium has been employed in previous works for the isolation and maintenance of endophytes from halophytes in SW Spain salt marshes (Mesa et al., 2015; Navarro-Torre et al., 2016). Plates were incubated at $28^{\circ} \mathrm{C}$ for $72 \mathrm{~h}$. Resulting colonies were selected and re-plated according to different colony morphology (colour, shape and surface) and microscopic observations (Gram staining and motility). Further strain species identification was carried out by phylogenetic analysis by sequencing of $16 \mathrm{~S}$ rDNA as explained in Mesa et al. (2015).

\subsection{Bacterial phenanthrene degradation capacity assay and design of the bacterial inoculation consortium}

Phenanthrene used in this study was purchased from Sigma-Aldrich (Spain), 98\% purity. $2 \mathrm{~g}$ Phe were dissolved in $100 \mathrm{ml}$ methanol (Panreac, Spain) to get a $2 \%$ stock solution. To assess the ability of $S$. densiflora endophytes to degrade Phe, a shaking flask method was carried out. The experiment was conducted using minimal medium containing per litre: $6 \mathrm{~g} \mathrm{Na}_{2} \mathrm{HPO}_{4}, 3 \mathrm{~g} \mathrm{KH}_{2} \mathrm{PO}_{4}, 17 \mathrm{~g} \mathrm{NaCl}$ (to keep the optimal saline concentration for endophytic isolates, this is, $0.3 \mathrm{M} \mathrm{NaCl}$ ), $5 \mathrm{~g}$ $\left(\mathrm{NH}_{4}\right)_{2} \mathrm{SO}_{4}$ (to promote the growth of biomass according to Pantsyrnaya et al. (2012)), $100 \mu \mathrm{l}$ trace elements solution (11.19 mg $\mathrm{MnSO}_{4} \cdot \mathrm{H}_{2} \mathrm{O}$, $10 \mathrm{mg} \mathrm{H} \mathrm{BO}_{3}, 78.22 \mathrm{mg} \mathrm{CuSO} \cdot 5 \mathrm{H}_{2} \mathrm{O}, 124.6 \mathrm{mg} \mathrm{ZnSO}_{4} \cdot 7 \mathrm{H}_{2} \mathrm{O}$ and $10 \mathrm{mg}$ $\mathrm{MoO}_{3}$ in $100 \mathrm{ml}$ sterile distilled water), $100 \mu \mathrm{l}$ iron solution $(100 \mathrm{mg}$ $\mathrm{FeSO}_{4} \cdot 7 \mathrm{H}_{2} \mathrm{O}$ in $10 \mathrm{ml}$ sterile distilled water), $1 \mathrm{ml} \mathrm{MgSO}_{4} \cdot 7 \mathrm{H}_{2} \mathrm{O} 1 \mathrm{M}$ and $100 \mu \mathrm{CaCl}_{2} 1 \mathrm{M} \mathrm{pH}$ was adjusted to 7 and the medium was autoclaved during 20 minat $121^{\circ} \mathrm{C} . \quad \mathrm{MgSO}_{4}$ and $\mathrm{CaCl}_{2}$ so- lutions were made separately, then filter sterilised $(0.22 \mu \mathrm{m})$ and aseptically added to autoclaved minimal medium. For the shaking flask method, empty $250 \mathrm{ml}$ Erlenmeyer flasks were autoclaved and let cool down. Next, $500 \mu \mathrm{l}$ of $2 \%$ Phe in methanol stock solution were added to the flasks under the hood. For control flasks, $500 \mu \mathrm{l}$ of methanol were used in the same conditions. Once the solvent had evaporated, the resulting crystalline Phe was resuspended in $100 \mathrm{ml}$ sterile minimal medium to give $100 \mathrm{mgl}^{-1}$ Phe. Finally, each flask was inoculated with a single strain. They were incubated in the dark on a shaker at $28^{\circ} \mathrm{C}$. $\mathrm{OD}_{600}$ was measured everyday during 8 days using a spectrophotometer (Lambda 25; PerkinElmer, USA). Bacterial strains showing notable growth during a week were selected to be part of a consortium for further plant inoculation. To ensure the viability of the final consortium, the selected strains were cultivated together to determine antagonistic activity against each other.

\subsection{Preparation of the bacterial inoculant solution}

Strains selected from the phenanthrene degradation assay were grown singly in $50 \mathrm{ml}$ of TSB medium $0.3 \mathrm{M} \mathrm{NaCl}$ contained in $250 \mathrm{ml}$ Erlenmeyer flasks and incubated under shaking conditions at $28^{\circ} \mathrm{C}$ during $18-24 \mathrm{~h}$. Then, cultures were centrifuged in $50 \mathrm{ml}$ Falcon tubes at $7000 \mathrm{rpm}$ during $10 \mathrm{~min}$, washed and finally resuspended in sterile physiological saline solution $(\mathrm{NaCl} 0.9 \% \mathrm{w} / \mathrm{v})$. Then, bacterial strains were mixed and suspended together to reach a suspension with $\mathrm{OD}_{600}=1.0$ (approximately $10^{8}$ cells $/ \mathrm{ml}$ ), which was used as the inoculant solution.

\subsection{Spartina densiflora phenanthrene tolerance and soil dissipation experiment}

In Spring 2014, S. densiflora plants were placed in square pots $(10 \mathrm{~cm} \times 10 \mathrm{~cm})$ with sandy soil (Typic Rhodoxeralf; see Redondo-Gómez et al. (2011) for physicochemical properties). Then, they were treated with a solution of Phe (Sigma) in acetone to get final concentrations in soil of 100 and $1000 \mathrm{mg} \mathrm{kg}^{-1}$ of Phe. The controls were treated with acetone. To get a homogenous mixture and induce acetone volatilization, a $2 \mathrm{~mm}$ mesh was used to sieve soil samples several times. Next, they were placed in the same greenhouse $\left(3^{\circ} 23^{\prime} \mathrm{N}, 5^{\circ} 59^{\prime} \mathrm{W}\right.$, Seville, Spain) with $21-25^{\circ} \mathrm{C}$ minimum - maximum temperatures, relative humidity of $40-60 \%$ and natural daylight $\left(200-1000 \mu \mathrm{mol} \mathrm{m}^{-2} \mathrm{~s}^{-1}\right)$. Then, pots were randomly assigned to four treatment groups: (1) non-inoculated $S$. densiflora, $\mathrm{Sd}^{-}$, (2) $S$. densiflora with bacterial inoculation, $\mathrm{Sd}^{+}$, (3) unplanted pots without inoculation, $\mathrm{U}^{-}$, and (4) unplanted pots with bacterial inoculation, $\mathrm{U}^{+} . \mathrm{U}^{-}$and $\mathrm{U}^{+}$were stablished to determine the basal Phe volatilization rate. In summary, twelve treatments were established: $\mathrm{Sd}^{-}$, $\mathrm{Sd}^{+}, \mathrm{U}^{+}$and $\mathrm{U}^{-} \times 0,100$ and $1000 \mathrm{mg} \mathrm{kg}^{-1}$ Phe (3 pots per tray, 1 tray per treatment, 36 pots in total). Each pot of $\mathrm{Sd}^{+}$and $\mathrm{U}^{+}$treatments were watered with $50 \mathrm{ml}$ of bacterial suspension prepared as detailed in 2.3. Once a week during the experimental period. $2 \mathrm{~L}$ of $20 \%$ Hoagland's solution were poured in the trays when beginning the experimentation. The levels of the solution in the trays were maintained to $1 \mathrm{~cm}$ depth during the study.

\subsection{Analysis of Spartina densiflora growth}

At the beginning of the experiment ten plants were collected, and three more were harvested from each treatment at the end of the experiment (33 days). Plants were dried at $80^{\circ} \mathrm{C}$ for $48 \mathrm{~h}$ and weighed. Then, S. densiflora relative growth rate (RGR) was calculated by using the formula (Hoffmann and Poorter, 2002):

$\mathrm{RGR}=(\ln \mathrm{Bf}-\ln \mathrm{Bi}) \times \mathrm{D}^{-1}\left(\mathrm{~g} \mathrm{~g}^{-1} \mathrm{day}^{-1}\right)$

where $\mathrm{Bf}=$ final dry mass, $\mathrm{Bi}=$ initial dry mass (an average of the ten 
plants dried at the beginning of the experiment) and $\mathrm{D}=$ duration of experiment (days).

\subsection{Determination of Spartina densiflora chlorophyll fluorescence}

Modulated chlorophyll fluorescence measurements were made at midday in randomly selected fully expanded leaves using a modulated fluorimeter (Mini-PAM, Heinz Walz, Germany) after 33 days of treatment initiation (three measurements per plant, $n=9$ ) on light (at $1600 \mu \mathrm{mol}$ photons $\mathrm{m}^{-2} \mathrm{~s}^{-1}$ ) and $30 \mathrm{~min}$ dark-adapted leaves. Light and dark energy yields of the Photosystem II (PSII) reaction centers were determined with a saturation pulse method as described by Schreiber et al. (1986), using a $0.8 \mathrm{~s}$ saturating light pulse with an intensity of $10,000 \mu \mathrm{mol} \mathrm{m}^{-2} \mathrm{~s}^{-1}$. Thus, maximum quantum efficiency of PSII photochemistry $\left(\mathrm{F}_{\mathrm{v}} / \mathrm{F}_{\mathrm{m}}\right)$, quantum efficiency of PSII ( $\Phi_{\mathrm{PSII}}$; Genty et al., 1989) and quantum yield of non-photochemical quenching $\left(\Phi_{\mathrm{NPQ}}=\left(\mathrm{Fs} / \mathrm{Fm}{ }^{\prime}\right)\right.$ - (Fs/Fm) (Porcel et al., 2015) were calculated using fluorescence parameters determined in both light- and dark-adapted states. These parameters provide information about plant photoinhibition level (Maxwell and Johnson, 2000) as well as of energy use efficiency in term of real PSII photochemistry efficiency and energy excess dissipation capacity (Lazár, 2015).

\subsection{Measurement of Spartina densiflora gas exchange}

Instantaneous leaf gas exchange measurements were performed with an open infrared gas analyzer system (LI-6400, Li-COR Inc., Lincoln, NE., USA) equipped with a light leaf chamber (Li-6400-02B, Li-Cor Inc.). Measurements were performed in the same leaf section of chlorophyll fluorescence measurements $(n=7) 33$ after the onset of the treatments. Net photosynthetic rate $\left(A_{\mathrm{N}}\right)$, stomatal conductance $\left(g_{\mathrm{s}}\right)$ and intercellular $\mathrm{CO}_{2}$ concentration $\left(C_{\mathrm{i}}\right)$ were all determined under the following settings inside the leaf chamber: a photosynthetic photon flux density (PPFD) of $1000 \mu \mathrm{mol} \mathrm{m}^{-2} \mathrm{~s}^{-1}$ (with $15 \%$ blue light to maximize stomatal aperture), vapour pressure deficit of $2.0-3.0 \mathrm{kPa}$, air temperature of around $25 \pm 2{ }^{\circ} \mathrm{C}$, relative humidity of $50 \pm 5$ and an ambient $\mathrm{CO}_{2}$ concentration $\left(C_{a}\right)$ of $400 \mu \mathrm{mol} \mathrm{mol}^{-1}$ air. All measurements were recorded between 10:00 to 13:00 and before to record each measurement, gas exchange was allowed to equilibrate (400 s). Photosynthetic area was approximated as the area of a trapezium. Finally, intrinsic water-use efficiency (iWUE) was calculated using $\mathrm{A}_{\mathrm{N}} / \mathrm{g}_{\mathrm{s}}$ ratio.

\subsection{Chemical analysis of soil and Spartina densiflora leaves and roots}

Phe concentration in soil was determinate in randomly collected $2.5 \mathrm{~g}$ samples of soil $(\mathrm{n}=3)$ after $0,10,16,23$ and 33 days after onset the experiment by high performance liquid chromatography (HPLC) using a Waters 600E chromatograph coupled to a Water 996 diode-array and Water 2475 fluorescence Detector. Phe soil extraction and chromatographic conditions details are provided in Redondo-Gómez et al. (2011). Furthermore, calcium (Ca), iron ( $\mathrm{Fe}$ ), potassium (K), magnesium $(\mathrm{Mg})$, sodium (Na), phosphorus (P) and sulphur (S) concentration in dry leaves and roots samples $(n=3)$ of $S$. densiflora were analysed by inductively coupled plasma (ICP-OES) spectroscopy (Thermo ICAP 6500 DUO, USA) in accordance with protocol described in Redondo-Gómez et al. (2011).

\subsection{Statistical analysis}

Statistical analysis was carried out using Statistica v. 10.0 (Statsoft Inc.). Data were first tested for normality with the Kolmogorov-Smirnov test and for homogeneity of variance with the Brown-Forsythe test. Significant test results were followed by Tukey test for identification of pairwise contrasts. Due to differences in nutrient content between $S$. densiflora tillers and roots, they were analysed independently, and then compared by the Student's t-test. Finally, taking into account our experimental design, data for remaining Phe in soil was nested to days of sampling, in order to avoid the masking effect linked with the highly differential Phe concentration in soil depending on the moment of the experimental period. In all cases, a significance level of $\mathrm{p}<0.05$ was used.

\section{Results}

\subsection{Bacterial characterization and strain selection for Spartina densiflora pot inoculation}

According to the morphology of the colonies and Gram staining, 30 different endophytes, 12 from roots and 18 from leaves, were isolated from $S$. densiflora sampled in the Odiel marshes. Most of the isolates, 26 strains, were Gram-negative rods. All the strains were tested for phenanthrene degradation. Strains ES7, ES8 and ES10 were selected based on the optical densities reached at $600 \mathrm{~nm}$ after eight days of incubation, being $0.18,0.24$ and 0.16 , respectively. The selected strains were identified based on their 16 rDNA sequence as Vibrio proteolyticus ES7, Pseudoalteromonas flavipulchra ES8 and Vibrio proteolyticus ES10 (Table 1).

\subsection{Spartina densiflora growth, photosynthesis and chlorophyll}

fluorescence response to bacterial inoculation in a range of phenanthrene concentrations

S. densiflora relative growth rate (RGR) tended to increase with bacterial inoculation for the three Phe soil concentrations tested, although there was not a significant difference between treatments $(p>0.05$; Fig. 1). The lowest RGR values were recorded for non-inoculated $S$. densiflora at $1000 \mathrm{mg} \mathrm{kg}^{-1}$ Phe, whereas inoculated S. densiflora at $100 \mathrm{mg} \mathrm{kg}^{-1}$ Phe reached the highest RGR data (Fig. 1).

After 33 days of treatment, significant differences were obtained for Net photosynthetic rate $\left(\mathrm{A}_{\mathrm{N}}\right)(\mathrm{p}<0.01$, Fig. 2) and stomatal conductance $\left(\mathrm{g}_{\mathrm{s}}\right)(\mathrm{p}<0.01$ and $\mathrm{p}<0.01$, Fig. 2$)$ in $S$. densiflora. Although no significant differences could be identified in intercellular $\mathrm{CO}_{2}$ concentration $\left(\mathrm{C}_{\mathrm{i}}\right)$ and intrinsic water use efficiency (iWUE) $(\mathrm{p}>0.05)$, trends in their results could be observed. $S$. densiflora $\mathrm{A}_{\mathrm{N}}, \mathrm{g}_{\mathrm{s}}$ and $\mathrm{C}_{\mathrm{i}}$ tended to increase for all Phe concentrations when bacteria treatment was applied (Fig. 2A, B and C). However, iWUE showed a mild descent in inoculated plants, which disappeared in $1000 \mathrm{mg} \mathrm{kg}^{-1}$ Phe (Fig. 2D).

Quantum efficiency of PSII ( $\left.\varphi_{\text {PSII }}\right)$ and quantum yield of non-photochemical quenching by regulated thermal dissipation $\left(\varphi_{\mathrm{NPQ}}\right)$ analysed for $S$. densiflora did not vary significantly between inoculation treatments without Phe in soil after 33 days ( $p>0.05$, Fig. 3B and C). Only values of $F_{v} / F_{m}$ changed significantly with the synergistic effect of Phe and inoculation ( $\mathrm{p}<0.01$, Fig. $3 \mathrm{~A}$ ), as seen by the increase observed in inoculated $S$. densiflora at $1000 \mathrm{mg} \mathrm{kg}^{-1}$ Phe after 33 days (Fig. 3A).

Table 1

Closest species to the phenanthrene degrading strains isolated from Spartina densiflora based on their $16 \mathrm{~S}$ rDNA sequence.

\begin{tabular}{|c|c|c|c|c|}
\hline Strain & $\begin{array}{l}\text { 16S rDNA sequenced } \\
\text { fragment (bp) }\end{array}$ & $\begin{array}{l}\text { Accession } \\
\text { No. }\end{array}$ & Related species & $\begin{array}{l}\text { Percent } \\
\text { identity }\end{array}$ \\
\hline ES7 & 1438 & KX529476 & $\begin{array}{l}\text { Vibrio } \\
\text { proteolyticus }\end{array}$ & 98,33 \\
\hline ES8 & 1413 & KX529477 & $\begin{array}{l}\text { Pseudoalteromonas } \\
\text { flavipulchra }\end{array}$ & 99,22 \\
\hline ES10 & 1418 & KX529478 & $\begin{array}{l}\text { Vibrio } \\
\text { proteolyticus }\end{array}$ & 98,80 \\
\hline
\end{tabular}




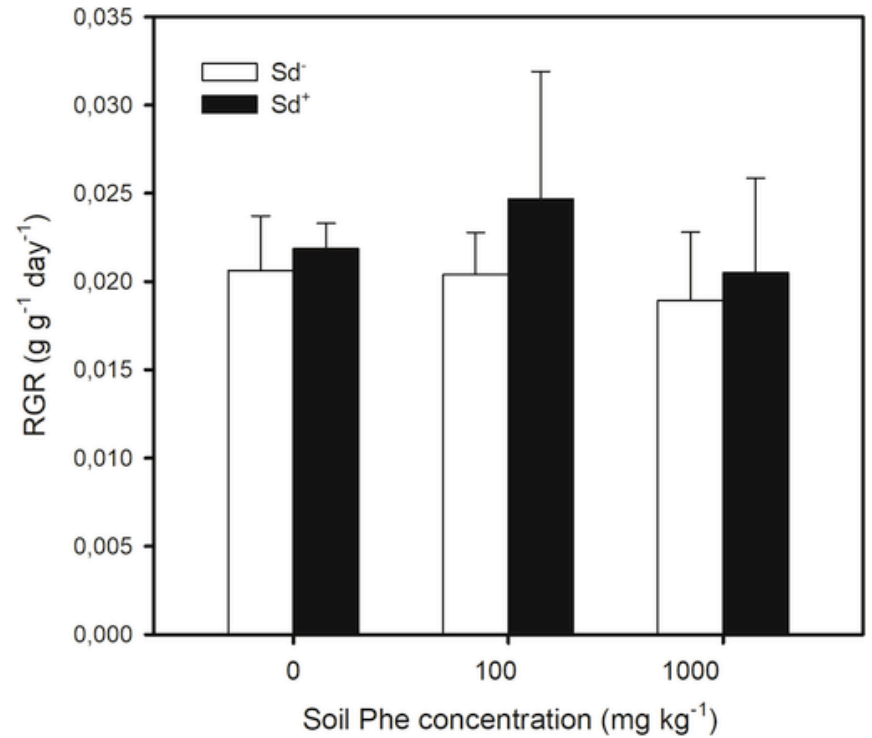

Fig. 1. Relative growth rate of Spartina densiflora in response to bacterial inoculation in a range of phenanthrene concentrations $(0,100$ and $1000 \mathrm{ppm})$ over 33 days. Values represent means \pm SE $(n=3)$.

\subsection{Ions accumulation in Spartina densiflora tissues after bacterial inoculation in a range of phenanthrene concentrations}

Generally, Ca, Fe and Na were found to be more concentrated in $S$. densiflora roots, whereas $\mathrm{K}, \mathrm{Mg}, \mathrm{P}$ and $\mathrm{S}$ levels were higher in tillers ( $t$-test, $\mathrm{p}<0.05$, Table 2). When focusing on Phe effect, non-inoculated
S. densiflora showed Fe concentrations significantly decreased in roots and tillers with Phe-amended soil. Conversely, $\mathrm{Mg}$ values tended to increase. In tillers, $\mathrm{Ca}$ and $\mathrm{P}$ concentrations augmented in the face of Phe presence, while Na and S decreased. Regarding roots, Ca levels diminished and Na augmented, contrary to the effect observed in tillers. On the other hand, when moving to bacterial inoculation effect on $S$. densiflora nutrient composition, Fe showed the most outstanding differences. This is, while Fe concentrations significantly decreased in tillers for non-inoculated plants, Fe in bacterial-inoculated $S$. densiflora tillers increased considerably. Also, $\mathrm{Fe}$ in $S$. densiflora roots remained quite similar in inoculated plants, whereas there was a significant decline of Fe concentration in non-inoculated $S$. densiflora roots at $100 \mathrm{mg} \mathrm{kg}^{-1} \mathrm{Phe}$ $(\mathrm{p}<0.05$, Table 2).

\subsection{Concentration of remaining phenanthrene in soil at the end of the experiment}

Clear differences in remaining soil Phe were detected among treatments in pots with starting $100 \mathrm{mg} \mathrm{kg}^{-1}$ Phe (Fig. 4A) and $1000 \mathrm{mg} \mathrm{kg}^{-1}$ Phe (Fig. 4B). The treatment which induced the highest soil Phe dissipation was, in both cases, the presence of non-inoculated $S$. densiflora $\left(\mathrm{Sd}^{-}\right)$, reaching in 16 days Phe soil removal rates of 95\% (Fig. 4A, black triangle) and 70\% (Fig. 4B, black triangle). In the same way, unplanted non-inoculated pots $\left(\mathrm{U}^{-}\right)$managed a considerable Phe dissipation rate at both starting concentrations, ranging from $80 \%$ (Fig. 4A, black circle) to $65 \%$ (Fig. 4B, black circle). However, differences between these non-inoculated pots, both planted $\left(\mathrm{Sd}^{-}\right)$and non-planted $\left(\mathrm{U}^{-}\right)$, were mostly counterbalanced after 33 days of treatment, when 99 and $90 \%$ of Phe in soil disappeared, respectively. The most striking results were those showed by inoculated pots, either unplanted or planted with $S$. densiflora $\left(\mathrm{U}^{+}\right.$and $\left.\mathrm{Sd}^{+}\right)$. At starting $100 \mathrm{mg} \mathrm{kg}^{-1}$ Phe in soil, unplanted pots inoculated with bacteria $\left(\mathrm{U}^{+}\right)$clearly showed the

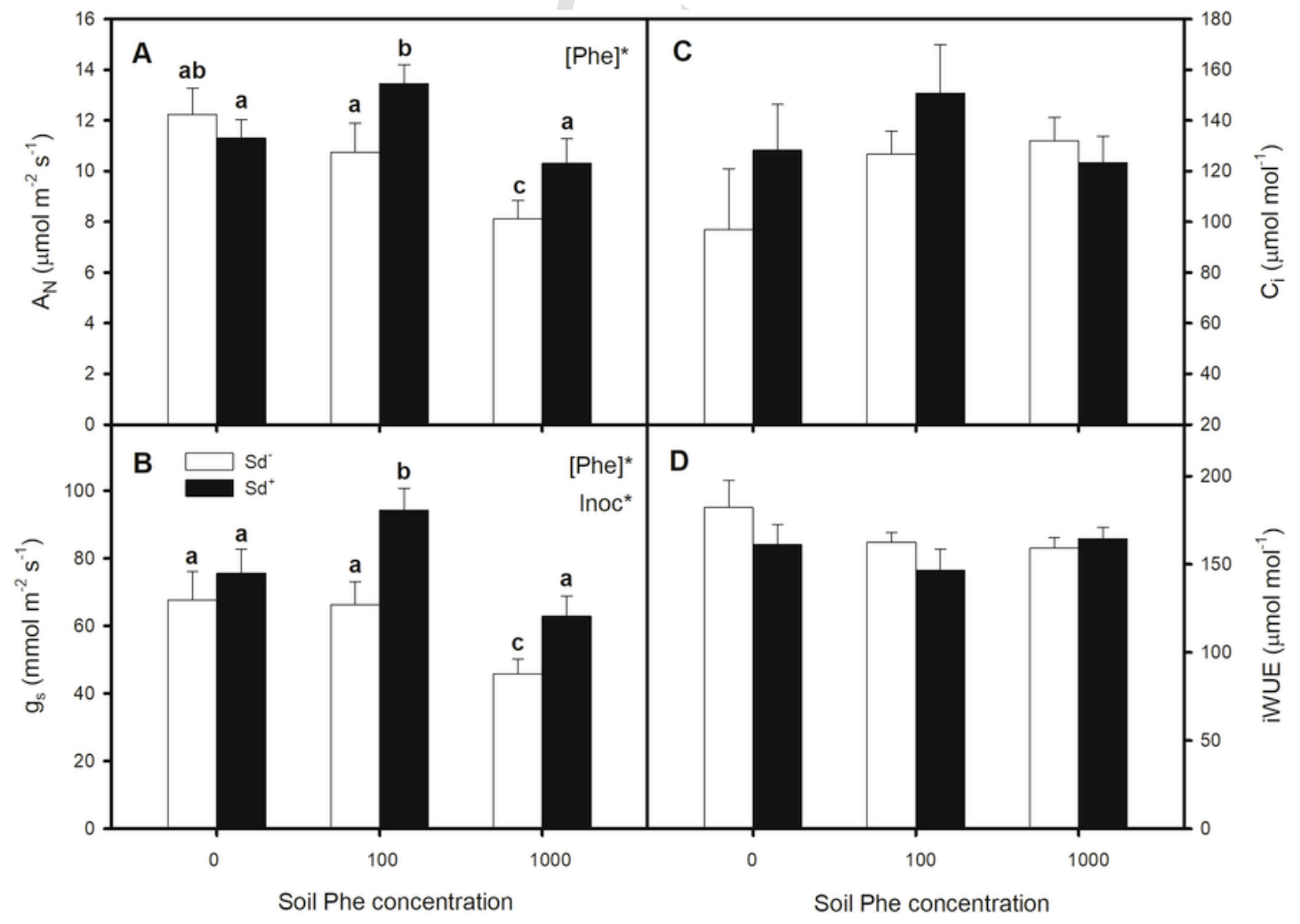

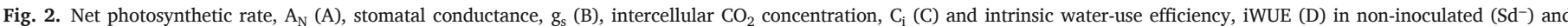

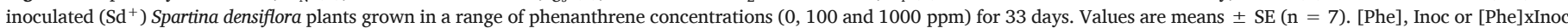

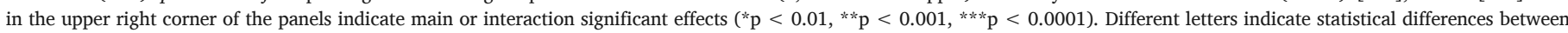
means $(\mathrm{p}<0.05)$. 


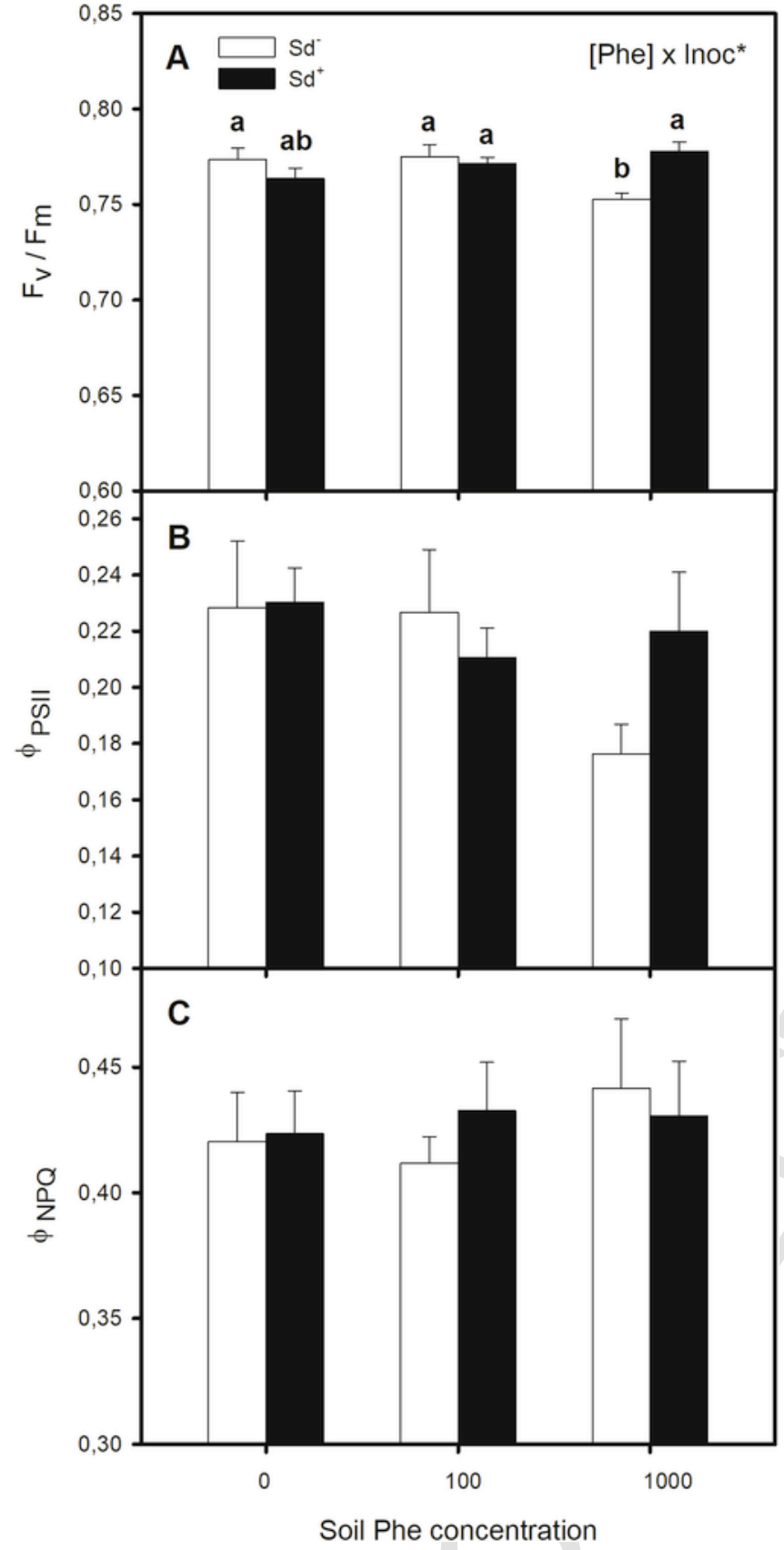

Fig. 3. Effect of inoculation with the endophytic consortium on maximum quantum efficiency of PSII photochemistry, $\mathrm{F}_{\mathrm{v}} / \mathrm{F}_{\mathrm{m}}(\mathrm{A})$, quantum efficiency, $\Phi_{\mathrm{PSII}}(\mathrm{B})$ and quantum yield of non-photochemical quenching, $\Phi_{\mathrm{NPQ}}(\mathrm{C})$ in leaves of Spartina densiflora plants grown in a range of phenanthrene concentrations $(0,100$ and $1000 \mathrm{ppm})$ for 33 days. Values are means \pm SE $(n=9)$. [Phe], Inoc or [Phe]xInoc in the upper right corner of the panels indicate main or interaction significant effects ( ${ }^{*} \mathrm{p}<0.01$, ${ }^{* *} \mathrm{p}<0.001$, ${ }^{* * *} \mathrm{p}<0.0001$ ). Different letters indicate statistical differences between means $(\mathrm{p}<0.05)$.

lowest Phe dissipation rate, with percentages around 55\% between days 10 and 25 (Fig. 4A, white circle). However, in the case of starting $1000 \mathrm{mg} \mathrm{kg}^{-1}$ Phe in soil, the tables turned and bacterial inoculation in $S$. densiflora $\left(\mathrm{Sd}^{+}\right)$became the treatment with lowest Phe dissipation rate, which hovered between 30 and 55\% from day 10-25 (Fig. 4B, white triangle). At the end of the experiment (33d), these inoculated treatments reached similar values to the non-inoculated ones (Fig. 4A and B).

\section{Discussion}

In this work, three $S$. densiflora endophytic bacteria were proved to survive using Phe as carbon source, identified as Vibrio proteolyticus ES7, Pseudoalteromonas flavipulchra ES8 and Vibrio proteolyticus ES10. They were subsequently employed for inoculation treatments under controlled conditions. In our greenhouse experiment, plant growth results obtained for non-inoculated $S$. densiflora were coincident with the ones obtained by Redondo-Gómez et al. (2011). In both studies, S. densiflora demonstrated a high tolerance to imposed Phe stress, since all plants survived to $1000 \mathrm{mg} \mathrm{kg}^{-1}$ Phe exposure. This is noteworthy, as previous studies demonstrated that $90 \mathrm{mg} \mathrm{kg}^{-1}$ Phe in soil are enough to cause plant toxicity (Lee et al., 2008), which detrimental effects have been described in several works (Pašková et al., 2006; Weisman et al., 2010). In this study, $S$. densiflora relative growth rate (RGR) did not show significant differences, although a trend of diminishing RGR could be observed in a range of Phe concentrations after 30 days of growth. Redondo-Gómez et al. (2011) also recorded no significant differences in RGR, as well as other authors for other wetland species treated with PAHs (Zhang et al., 2010). After treatment with bacterial inoculation, $S$. densiflora RGR increased compared to the non-inoculated control in a range of Phe, but not significantly. Moving to $S$. densiflora gas exchange and chlorophyll fluorescence results, those registered in our work for non-inoculated $S$. densiflora also coincide with the ones obtained by Redondo-Gómez et al. (2011), showing decreased $A_{N}$ and $g_{s}$ values, with an increase in $\mathrm{C}_{\mathrm{i}}$. Oguntimehin et al. (2008) got similar results for Pinus densiflora exposed to different PAHs. Bioaugmentation with indigenous Phe-degrading bacteria slightly improved $S$. densiflora fitness at the end of the experiment, as in case of $A_{N}, g_{s}, C_{i}, F_{v} / F_{m}$ and $\varphi_{\text {PSII }}$ with increasing Phe in soil. Continuous intermediate measurements of gas exchange and fluorescence in the present study were not carried out, as they were checked in our previous experiment (7, 10 and 30 days after onset experiment) (Redondo-Gómez et al., 2011), confirming a high Phe tolerance of $S$. densiflora photosynthetic apparatus functionality. However, differences between treatments were not as evident as the ones obtained in previous studies for inoculated $S$. densiflora in heavy metal polluted soils (Mateos-Naranjo et al., 2015; Paredes-Páliz et al., 2017). In them, authors recorded for inoculated $S$. densiflora, RGR increments up to $20 \%, 2$-fold increases for $\mathrm{A}_{\mathrm{N}}$ and $\mathrm{g}_{\mathrm{s}}, 35 \%$ augmented iWUE, and higuer $\mathrm{F}_{\mathrm{v}} / \mathrm{F}_{\mathrm{m}}$ and $\varphi_{\text {PSII }}$ values, compared to the non-inoculated controls (Mateos-Naranjo et al., 2015; Paredes-Páliz et al., 2017). These differences with regard to our results may be due to the fact that it has been recommended the use of bacteria having pollutant-degrading as well as plant growth promoting activities, as it improves the phytoremediation process in a greater extent than bacteria exhibiting only one of them (Dashti et al., 2009; Glick, 2010; Khan et al., 2013). In this work, unlike previous studies by (Mateos-Naranjo et al., 2015; Paredes-Páliz et al., 2017), plant growth promoting properties of isolated endophytes were not tested, as we focused on phenanthrene degrading capabilities.

As for $S$. densiflora nutrient acquisition, no general pattern was observed after inoculation. The content of some nutrients in leaves and roots, like $\mathrm{Ca}$, decreased after 33 days of experiment in Phe-amended soils, maybe due to the fact that hydrophobic nature of hydrocarbons may hinder soil water and nutrient absorption in plants (Khan et al., 2013).

The most striking outcomes of our study were those for soil Phe dissipation. As previously described by Redondo-Gómez et al. (2011), we obtained a more marked rate of Phe disappearance in soils planted with S. densiflora (7\% in this study, 6\% for Redondo-Gómez et al., 2011) rather than bulk soil. Other authors, as Cheema et al. (2010) and Lee et al. (2008) found up to 3\% Phe disappearance in planted soils. Taking into account PAHs health risk, even at very low concentrations 
Table 2

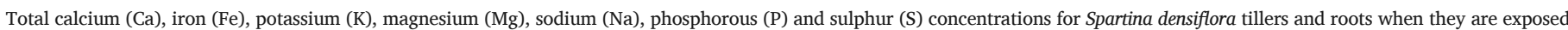

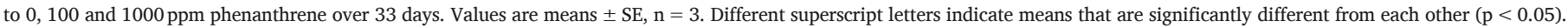

\begin{tabular}{|c|c|c|c|c|c|c|c|c|c|}
\hline Tissue & Phe $\left(\mathrm{mg} \mathrm{Kg}{ }^{-1}\right)$ & Treatment & $\mathrm{Ca}\left(\mathrm{mg} \mathrm{g}^{-1}\right)$ & $\mathrm{Fe}\left(\mathrm{mg} \mathrm{Kg} \mathrm{K}^{-1}\right)$ & $\mathrm{K}\left(\mathrm{mg} \mathrm{g}^{-1}\right)$ & $\mathrm{Mg}\left(\mathrm{mg} \mathrm{g}^{-1}\right)$ & $\mathrm{Na}\left(\mathrm{mg} \mathrm{g}^{-1}\right)$ & $\mathrm{P}\left(\mathrm{mg} \mathrm{g}^{-1}\right)$ & $\mathrm{S}\left(\mathrm{mg} \mathrm{g}^{-1}\right)$ \\
\hline \multirow[t]{6}{*}{ Tillers } & \multirow[t]{2}{*}{0} & $\mathrm{Sd}^{-}$ & $0,35 \pm 0,03^{\mathrm{a}}$ & $867,73 \pm 31,91^{\mathrm{a}}$ & $2,16 \pm 0,08^{\mathrm{ac}}$ & $0,35 \pm 0,01^{\mathrm{a}}$ & $0,74 \pm 0,02^{\mathrm{a}}$ & $0,14 \pm 0,00^{\mathrm{a}}$ & $0,69 \pm 0,03^{\mathrm{a}}$ \\
\hline & & $\mathrm{Sd}^{+}$ & $0,34 \pm 0,03^{\mathrm{a}}$ & $196,52 \pm 5,13^{\mathrm{b}}$ & $1,98 \pm 0,08^{\mathrm{ab}}$ & $0,39 \pm 0,01^{\mathrm{bd}}$ & $0,76 \pm 0,02^{\mathrm{a}}$ & $0,17 \pm 0,00^{\mathrm{b}}$ & $0,57 \pm 0,03^{b}$ \\
\hline & \multirow[t]{2}{*}{100} & $\mathrm{Sd}^{-}$ & $0,38 \pm 0,04^{\mathrm{ab}}$ & $337,67 \pm 7,70^{c}$ & $2,20 \pm 0,06^{c}$ & $0,36 \pm 0,01^{\mathrm{ac}}$ & $0,72 \pm 0,01^{\mathrm{a}}$ & $0,17 \pm 0,00^{\mathrm{b}}$ & $0,51 \pm 0,01^{\mathrm{b}}$ \\
\hline & & $\mathrm{Sd}^{+}$ & $0,46 \pm 0,05^{\mathrm{ab}}$ & $331,05 \pm 9,12^{\mathrm{c}}$ & $1,88 \pm 0,04^{b}$ & $0,42 \pm 0,00^{\mathrm{b}}$ & $0,62 \pm 0,01^{b}$ & $0,18 \pm 0,00^{\mathrm{bd}}$ & $0,57 \pm 0,02^{\mathrm{b}}$ \\
\hline & \multirow[t]{2}{*}{1000} & $\mathrm{Sd}^{-}$ & $0,48 \pm 0,05^{\mathrm{b}}$ & $167,06 \pm 1,39^{b}$ & $1,95 \pm 0,05^{\mathrm{bd}}$ & $0,41 \pm 0,00^{\mathrm{b}}$ & $0,66 \pm 0,00^{\mathrm{b}}$ & $0,21 \pm 0,00^{c}$ & $0,53 \pm 0,01^{\mathrm{b}}$ \\
\hline & & $\mathrm{Sd}^{+}$ & $0,46 \pm 0,04^{\mathrm{ab}}$ & $604,28 \pm 15,71^{d}$ & $2,10 \pm 0,07^{\text {acd }}$ & $0,38 \pm 0,01^{\mathrm{cd}}$ & $0,55 \pm 0,01^{c}$ & $0,19 \pm 0,00^{d}$ & $0,55 \pm 0,02^{\mathrm{b}}$ \\
\hline \multirow[t]{6}{*}{ Roots } & \multirow[t]{2}{*}{0} & $\mathrm{Sd}^{-}$ & $0,70 \pm 0,04^{\mathrm{a}}$ & $6431,82 \pm 285,84^{\mathrm{a}}$ & $0,96 \pm 0,02^{\mathrm{a}}$ & $0,22 \pm 0,00^{\mathrm{a}}$ & $0,55 \pm 0,02^{\mathrm{a}}$ & $0,08 \pm 0,00^{\mathrm{a}}$ & $0,22 \pm 0,01^{\mathrm{ad}}$ \\
\hline & & $\mathrm{Sd}^{+}$ & $0,35 \pm 0,02^{\mathrm{b}}$ & $6550,86 \pm 398,70^{\mathrm{a}}$ & $1,23 \pm 0,03^{\mathrm{b}}$ & $0,26 \pm 0,01^{\mathrm{b}}$ & $0,65 \pm 0,00^{\mathrm{b}}$ & $0,09 \pm 0,00^{\mathrm{b}}$ & $0,26 \pm 0,00^{\mathrm{b}}$ \\
\hline & \multirow[t]{2}{*}{100} & $\mathrm{Sd}^{-}$ & $0,52 \pm 0,02^{c}$ & $4118,14 \pm 167,17^{b}$ & $1,16 \pm 0,08^{\mathrm{b}}$ & $0,29 \pm 0,01^{\mathrm{bc}}$ & $0,81 \pm 0,03^{c}$ & $0,13 \pm 0,00^{c}$ & $0,24 \pm 0,01^{\mathrm{bd}}$ \\
\hline & & $\mathrm{Sd}^{+}$ & $0,50 \pm 0,02^{c}$ & $6906,52 \pm 311,19^{a}$ & $1,32 \pm 0,04^{b c}$ & $0,32 \pm 0,00^{c}$ & $0,95 \pm 0,00^{\mathrm{d}}$ & $0,10 \pm 0,00^{\mathrm{bd}}$ & $0,23 \pm 0,00^{\text {ad }}$ \\
\hline & \multirow[t]{2}{*}{1000} & $\mathrm{Sd}^{-}$ & $0,51 \pm 0,04^{c}$ & $6728,43 \pm 299,43^{a}$ & $1,18 \pm 0,04^{\mathrm{b}}$ & $0,29 \pm 0,01^{\mathrm{bc}}$ & $0,81 \pm 0,01^{\mathrm{c}}$ & $0,11 \pm 0,01^{\mathrm{d}}$ & $0,18 \pm 0,00^{c}$ \\
\hline & & $\mathrm{Sd}^{+}$ & $0,44 \pm 0,02^{\mathrm{bc}}$ & $6878,76 \pm 681,53^{\mathrm{a}}$ & $1,44 \pm 0,12^{\mathrm{c}}$ & $0,32 \pm 0,02^{c}$ & $0,80 \pm 0,05^{c}$ & $0,10 \pm 0,01^{\mathrm{b}}$ & $0,21 \pm 0,01^{\mathrm{a}}$ \\
\hline
\end{tabular}

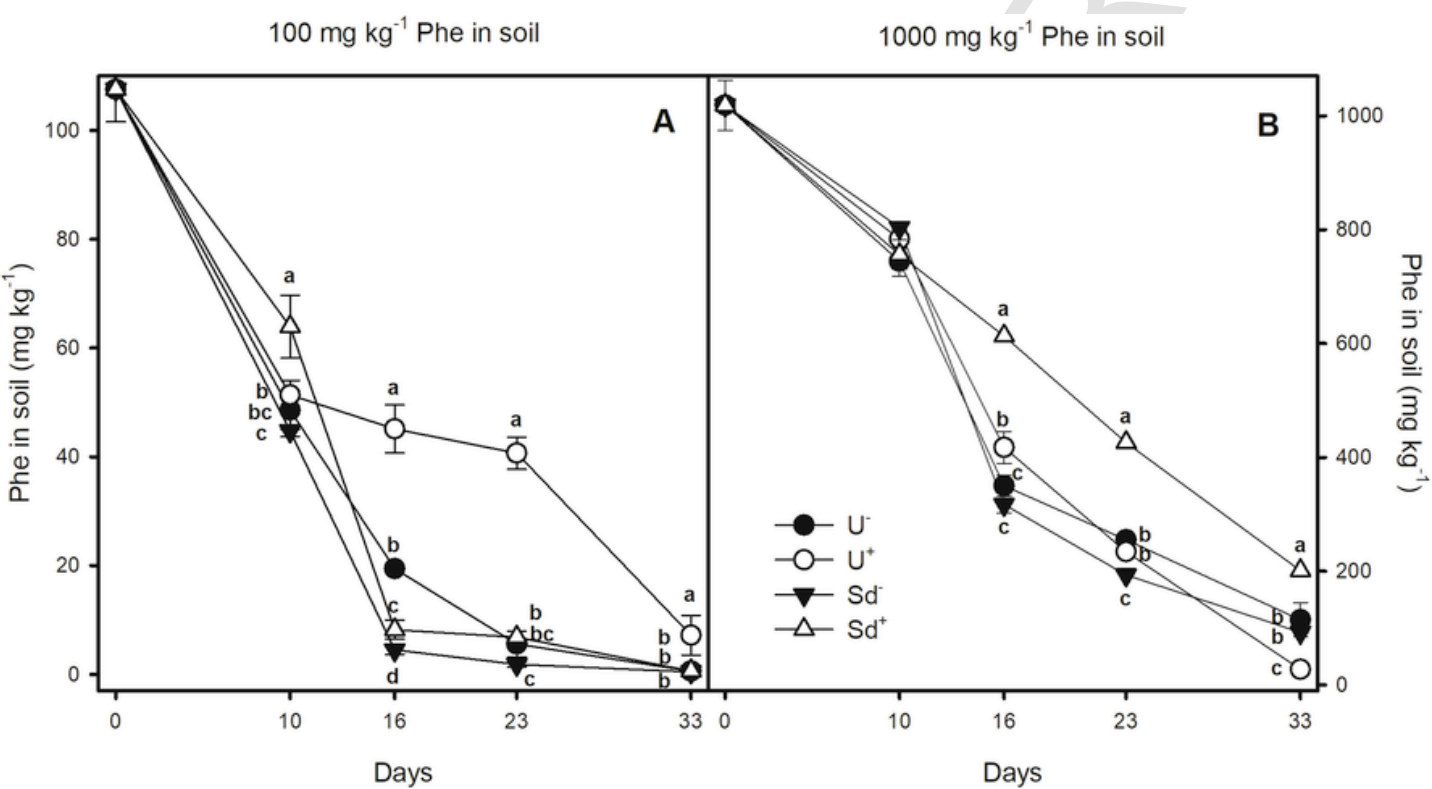

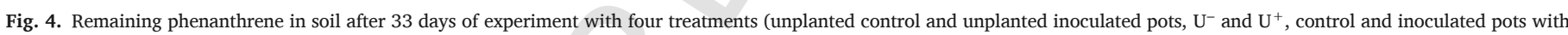

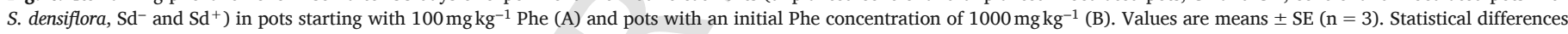
between means at the same day are indicated by different letters $(\mathrm{p}<0.05)$.

(Lee et al., 2008), any dissipation enhancement is meaningful. What surprised the more were the results obtained for inoculated treatments. While soil planted with inoculated $S$. densiflora showed a similar Phe dissipation response than the non-inoculated treatments at $100 \mathrm{mg} \mathrm{kg}^{-1}$ Phe, this treatment notably showed the lowest Phe dissipation rate at $1000 \mathrm{mg} \mathrm{kg}^{-1}$ Phe, reaching a $30 \%$ below non-inoculated $S$. densiflora and $23 \%$ less than bulk soil. This response may be due to an effect at the soil level, as we observed that bulk soil treated with bacteria at $100 \mathrm{mg} \mathrm{kg}^{-1}$ Phe retained the PAH in a great extent during the first three weeks, coinciding with weekly inoculation treatments. However, this response in bulk soil treated with bacteria was not observed at $1000 \mathrm{mg} \mathrm{kg}^{-1}$ Phe, probably due to the fact that higher quantities of Phe in soil may show higher volatilization rates. Both plants and their microbiome need a convenient soil environment for effective phytoremediation of organic contaminants. Soil properties affect plant fitness and growth, but also survival, colonization and metabolic activities of inoculated bacteria, thus influencing the biodegradation potential (Oliveira et al., 2015). For example, Afzal et al. (2011) reported that soil type indirectly affected biodegradation of organic pollutants due to a direct effect on bacterial dynamics. In their experiment, bacterial colonization, gene expression and consequently, PAH degradation, were significantly higher in loamy soils compared to those in other sandy soils. Data obtained in our work support this theory, as bacteria inoculation did not perturbed $S$. densiflora fitness, which could be a reason for diminished PAH soil removal (Khan et al., 2013). In a future research involving soil Phe phytoremediation, it would be of great interest to monitor several aspects, such as bacterial consortium survival, gene expression or metabolic activity, to get clearer evidence about the functionality of the microorganisms assayed (Oliveira et al., 2015).

\section{Conclusion}

The major finding of this study was that, contrary to our initial hypothesis, bacterial inoculation on $S$. densiflora did not significantly increase its inherent phenanthrene soil dissipation capacity in our greenhouse conditions. Nevertheless, this statement should be considered cautiously, inasmuch as colonization, gene expression and PAH degradation are heavily influenced by soil type and characteristics. It may therefore be advisable to provide effective follow-up of bacterial colonization and survival as well as to track metabolic activity in soil during phytoremediation of Phe polluted soils. 


\section{Conflicts of interest}

The authors declare that there is no conflict of interests regarding the publication of this paper.

\section{Acknowledgements}

This work has been supported by Ministerio de Economía y Competitividad (CGL2016-75550-R, AEI/FEDER, UE). J.A. Pérez-Romero thanks Ministerio de Educación, Cultura y Deporte for its personal financial support (FPU014/03987). S. Navarro-Torre thanks Junta de Andalucía and J.M. Barcia-Piedras thanks INIA for their personal financial supports. We thank the University of Seville Greenhouse General Services (CITIUS) for their collaboration, and Abraham D. Sánchez Cadena for kindly providing help with bacteria analysis. We are also grateful for constructive comments provided for reviewers, which greatly improved the draft manuscript.

\section{References}

Afzal, M., Yousaf, S., Reichenauer, T.G., Kuffner, M., Sessitsch, A., 2011. Soil type affects plant colonization, activity and catabolic gene expression of inoculated bacterial strains during phytoremediation of diesel. J. Hazard Mater. 186, 1568-1575 https:// doi.org/10.1016/j.jhazmat.2010.12.040.

Arthur, E.L., Rice, Pamela J., Rice, Patricia J., Anderson, T.A., Baladi, S.M., Henderson, K.L.D., Coats, J.R., 2005. Phytoremediation - an overview. CRC Crit. Rev. Plant Sci. 24, 109-122 https://doi.org/10.1080/07352680590952496.

Baker, J.M., 1970. The effects of oils on plants. Environ. Pollut. 1, 27-44 https://doi.org/ 10.1016/0013-9327(70)90004-2.

Cambrollé, J., Redondo-Gómez, S., Mateos-Naranjo, E., Figueroa, M.E., 2008. Comparison of the role of two Spartina species in terms of phytostabilization and bioaccumulation of metals in the estuarine sediment. Mar. Pollut. Bull. 56, 2037-2042 https://doi.org/ 10.1016/j.marpolbul.2008.08.008.

Cavé-Radet, A., Salmon, A., Lima, O., Ainouche, M.L., El Amrani, A., 2019. Increased tolerance to organic xenobiotics following recent allopolyploidy in Spartina (Poaceae). Plant Sci. 280, 143-154 https://doi.org/10.1016/j.plantsci.2018.11.005.

Dashti, N., Khanafer, M., El-Nemr, I., Sorkhoh, N., Ali, N., Radwan, S., 2009. The potential of oil-utilizing bacterial consortia associated with legume root nodules for cleaning oily soils. Chemosphere 74, 1354-1359 https://doi.org/10.1016/j.chemosphere. 2008.11.028.

Day, J.W., Kemp, W.M., Yáñez-Arancibia, A., Crump, B.C., 2013. Estuarine Ecology. Wiley.

Dumas, A.S., Taconnat, L., Barbas, E., Rigaill, G., Catrice, O., Bernard, D., Benamar, A., Macherel, D., El Amrani, A., Berthomé, R., 2016. Unraveling the early molecular and physiological mechanisms involved in response to phenanthrene exposure. BMC Genomics 17, 818 https://doi.org/10.1186/s12864-016-3133-0.

El Amrani, A., Dumas, A.S., Wick, L.Y., Yergeau, E., Berthomé, R., 2015. "Omics” insights into PAH degradation toward improved green remediation biotechnologies. Environ. Sci. Technol. 49, 11281-11291 https://doi.org/10.1021/acs.est.5b01740.

Genty, B., Briantais, J.M., Baker, N.R., 1989. The relationship between the quantum yield of photosynthetic electron transport and quenching of chlorophyll fluorescence. Biochim. Biophys. Acta 990, 87-92 https://doi.org/10.1016/S0304-4165(89)800169.

Glick, B.R., 2010. Using soil bacteria to facilitate phytoremediation. Biotechnol. Adv. 28, 367-374 https://doi.org/10.1016/j.biotechadv.2010.02.001.

Hoffmann, W.A., Poorter, H., 2002. Avoiding bias in calculations of relative growth rate. Ann. Bot. 80, 37-42 https://doi.org/10.1093/aob/mcf140.

Hong, Y., Liao, D., Chen, J., Khan, S., Su, J., Li, H., 2015. A comprehensive study of the impact of polycyclic aromatic hydrocarbons (PAHs) contamination on salt marsh plants Spartina alterniflora: implication for plant-microbe interactions in phytoremediation. Environ. Sci. Pollut. Res. 22, 7071-7081 https://doi.org/10.1007/s11356-014-39126.

Khan, S., Afzal, M., Iqbal, S., Khan, Q.M., 2013. Plant-bacteria partnerships for the remediation of hydrocarbon contaminated soils. Chemosphere 90, 1317-1332 https://doi. org/10.1016/j.chemosphere.2012.09.045.

Launen, L.A., Dutta, J., Turpeinen, R., Eastep, M.E., Dorn, R., Buggs, V.H., Leonard, J.W., Häggblom, M.M., 2008. Characterization of the indigenous PAH-degrading bacteria of Spartina dominated salt marshes in the New York/New Jersey Harbor. Biodegradation 19, 347-363 https://doi.org/10.1007/s10532-007-9141-7.

Lazár, D., 2015. Parameters of photosynthetic energy partitioning. J. Plant Physiol. 175, 131-147 https://doi.org/10.1016/j.jplph.2014.10.021.

Lee, S.H., Lee, W.S., Lee, C.H., Kim, J.G., 2008. Degradation of phenanthrene and pyrene in rhizosphere of grasses and legumes. J. Hazard Mater. 153, 892-898 https://doi. org/10.1016/j.jhazmat.2007.09.041.
Mackova, M., Dowling, D., Macek, T., 2006. Phytoremediation and Rhizoremediation, Focus on Biotechnology. Springer Netherlands.

Mateos-Naranjo, E., Mesa, J., Pajuelo, E., Perez-Martin, A., Caviedes, M.A., Rodríguez-Llorente, I.D., 2015. Deciphering the role of plant growth-promoting rhizobacteria in the tolerance of the invasive cordgrass Spartina densiflora to physicochemical properties of salt-marsh soils. Plant Soil 394, 45-55 https://doi.org/10. 1007/s11104-015-2504-7.

Maxwell, K., Johnson, G.N., 2000. Chlorophyll fluorescence - a practical guide. J. Exp. Bot. 51, 659-668 https://doi.org/10.1093/jxb/51.345.659.

Mesa, J., Mateos-naranjo, E., Caviedes, M.A., Redondo-gómez, S., Pajuelo, E., Rodríguez-llorente, I.D., 2015. Endophytic cultivable bacteria of the metal bioaccumulator Spartina maritima improve plant growth but not metal uptake in polluted marshes soils. Front. Microbiol. 6, 1-15 https://doi.org/10.3389/fmicb.2015.01450.

Mumtaz, M., George, J., 1995. Toxicological Profile for Polycyclic Aromatic Hydrocarbons. Agency for Toxic Substances and Disease Registry, U.S. Department of Health and Human Services https://doi.org/10.3109/15569529909037564.

Navarro-Torre, S., Mateos-Naranjo, E., Caviedes, M.A., Pajuelo, E., Rodríguez-Llorente, I.D., 2016. Isolation of plant-growth-promoting and metal-resistant cultivable bacteria from Arthrocnemum macrostachyum in the Odiel marshes with potential use in phytoremediation. Mar. Pollut. Bull. 110, 133-142 https://doi.org/10.1016/j.marpolbul. 2016.06.070.

Oguntimehin, I., Nakatani, N., Sakugawa, H., 2008. Phytotoxicities of fluoranthene and phenanthrene deposited on needle surfaces of the evergreen conifer, Japanese red pine (Pinus densiflora Sieb. et Zucc.). Environ. Pollut. 154, 264-271 https://doi.org/ 10.1016/j.envpol.2007.10.039.

Oliveira, V., Gomes, N., Almeida, A., Silva, A.M.S., Silva, H., Cunha, , 2015. Microbe-assisted phytoremediation of hydrocarbons in estuarine environments. Microb. Ecol. 69, 1-12 https://doi.org/10.1007/s00248-014-0455-9.

Pandey, J., Chauhan, A., Jain, R.K., 2009. Integrative approaches for assessing the ecological sustainability of in situ bioremediation. FEMS Microbiol. Rev. 33, 324-375 https: //doi.org/10.1111/j.1574-6976.2008.00133.x.

Pantsyrnaya, T., Delaunay, S., Goergen, J.-L., Guédon, E., Paris, C., Poupin, P., Guseva, E., Boudrant, J., 2012. Biodegradation of phenanthrene by Pseudomonas putida and a bacterial consortium in the presence and in the absence of a surfactant. Indian $\mathrm{J}$. Microbiol. 52, 420-426 https://doi.org/10.1007/s12088-012-0265-z.

Paredes-Páliz, K.I., Mateos-Naranjo, E., Doukkali, B., Caviedes, M.A., Redondo-Gómez, S., Rodríguez-Llorente, I.D., Pajuelo, E., 2017. Modulation of Spartina densiflora plant growth and metal accumulation upon selective inoculation treatments: a comparison of gram negative and gram positive rhizobacteria. Mar. Pollut. Bull. 125, 77-85 https: //doi.org/10.1016/j.marpolbul.2017.07.072.

Pašková, V., Hilscherová, K., Feldmannová, M., Bláha, L., 2006. Toxic effects and oxidative stress in higher plants exposed to polycyclic aromatic hydrocarbons and their N-heterocyclic derivatives. Environ. Toxicol. Chem. 25, 3238-3245 https://doi.org/ 10.1897/06-162R.1.

Pilon-Smits, E., 2005. Phytoremediation. Annu. Rev. Plant Biol. 56, 15-39 https://doi.org/ 10.1146/annurev.arplant.56.032604.144214.

Porcel, R., Redondo-Gómez, S., Mateos-Naranjo, E., Aroca, R., Garcia, R., Ruiz-Lozano, J.M., 2015. Arbuscular mycorrhizal symbiosis ameliorates the optimum quantum yield of photosystem II and reduces non-photochemical quenching in rice plants subjected to salt stress. J. Plant Physiol. 185, 75-83 https://doi.org/10.1016/j.jplph. 2015.07.006

Redondo-Gómez, S., 2013. Bioaccumulation of heavy metals in Spartina. Funct. Plant Biol. 40 (9), 913 https://doi.org/10.1071/FP12271.

Redondo-Gómez, S., Andrades-Moreno, L., Parra, R., Valera-Burgos, J., Real, M., Mateos-Naranjo, E., Cox, L., Cornejo, J., 2011. Spartina densiflora demonstrates high tolerance to phenanthrene in soil and reduces it concentration. Mar. Pollut. Bull. 62 , 1800-1808 https://doi.org/10.1016/j.marpolbul.2011.05.018.

Schreiber, U., Schliwa, U., Bilger, W., 1986. Continuous recording of photochemical and non-photochemical chlorophyll fluorescence quenching with a new type of modulation fluorometer. Photosynth. Res. 10, 51-62 https://doi.org/10.1007/BF00024185.

Shiri, M., Rabhi, M., Abdelly, C., Bouchereau, A., El Amrani, A., 2016. Moderate salinity reduced phenanthrene-induced stress in the halophyte plant model Thellungiella salsuginea compared to its glycophyte relative Arabidopsis thaliana: cross talk and metabolite profiling. Chemosphere 155, 453-462 https://doi.org/10.1016/j. chemosphere.2016.04.080.

Shiri, M., Rabhi, M., Amrani, A. El, Abdelly, C., 2015. The halophyte Cakile maritima reduces phenanthrene phytotoxicity. Int. J. Phytoremediation 17, 925-928 https://doi org/10.1080/15226514.2014.1003784.

Smith, K.E., Schwab, A.P., Banks, M.K., 2008. Dissipation of PAHs in saturated, dredged sediments: a field trial. Chemosphere 72, 1614-1619 https://doi.org/10.1016/j chemosphere.2008.03.020.

Van Oosten, M.J., Maggio, A., 2015. Functional biology of halophytes in the phytoremediation of heavy metal contaminated soils. Environ. Exp. Bot. 111, 135-146 https://doi. org/10.1016/j.envexpbot.2014.11.010

Watts, A.W., Ballestero, T.P., Gardner, K.H., 2006. Uptake of polycyclic aromatic hydrocarbons (PAHs) in salt marsh plants Spartina alterniflora grown in contaminated sediments. Chemosphere 62, 1253-1260 https://doi.org/10.1016/j.chemosphere.2005. 07.006.

Weisman, D., Alkio, M., Colón-Carmona, A., 2010. Transcriptional responses to polycyclic aromatic hydrocarbon-induced stress in. BMC Plant Biol. 10, 59.

Zhang, Z., Rengel, Z., Meney, K., 2010. Polynuclear aromatic hydrocarbons (PAHs) differentially influence growth of various emergent wetland species. J. Hazard Mater. 182, 689-695 https://doi.org/10.1016/j.jhazmat.2010.06.087. 